\title{
Terrorists, Freedom Fighters and Refugees: Non-Political Crimes in Article $1 F(b)$ of the Refugee Convention
}

\begin{abstract}
Jasmine Still
This essay deals with the topical issue of the circumstances under which criminals can be refugees. Article $1 \mathrm{~F}(\mathrm{~b})$ of the Convention Relating to the Status of Refugees (the Refugee Convention) denies refugee status to people who have "committed a serious non-political crime". Thus, if a person has committed a serious crime that was political in nature it does not preclude them from enjoying the benefits of refugee status.

There are many competing interpretations of 'non-political', including the predominance test, which is the approach adopted by the United Nations High Commissioner for Refugees. This test states that a crime will be political if a political purpose is the predominant characteristic of the crime.

This essay assesses the predominance test against the rules for treaty interpretation set out in Article 31 of the Vienna Convention on the Law of Treaties. This involves examining whether this interpretation is in good faith and accords with the ordinary meaning, context and object and purpose of Article $1 \mathrm{~F}(\mathrm{~b})$ of the Refugee Convention.

This essay concludes that the predominance test is a highly appropriate interpretation of Article $1 \mathrm{~F}(\mathrm{~b})$. In the interests of consistency it should therefore be adopted by all the parties to the Refugee Convention.
\end{abstract}

\section{A. Introduction}

\section{The Importance of Article 1F(b)}

Article $1 \mathrm{~F}(\mathrm{~b})$ of the Convention Relating to the Status of Refugees (Refugee Convention) denies the benefits of refugee status to a person when there are serious reasons for considering that "he has committed a serious non-political crime outside the country of refuge prior to his admission to that country as a 
refugee", 1 even if he has a "well-founded fear of being persecuted for reasons of race, religion, nationality, membership of a particular social group or political opinion" ${ }^{2}$ As such, it can have devastating consequences because it places the person at risk of being returned to face persecution in their state of origin. ${ }^{3}$ Furthermore, with the increase in violent conflicts involving breaches of human rights and deliberate attacks on civilians, more and more people are potentially falling within its scope. ${ }^{4}$ Thus, as Article $1 \mathrm{~F}(\mathrm{~b})$ is increasingly relevant to refugee status determinations, it is vital to know what this exclusion clause means to ensure that refugee status determinations are fair and consistent between countries. ${ }^{5}$ Unfortunately, despite this exclusion clause's brevity and ostensible simplicity, there are many controversies about how to interpret it. ${ }^{6}$

\section{The Controversy Surrounding the Interpretation of 'Non-Political'}

One of the most intractable and complex debates is about the meaning of "nonpolitical'. ${ }^{7}$ There is broad agreement that certain crimes, such as treason, are political. ${ }^{8}$ Furthermore, it is clear that crimes with purely personal motives, such as crimes of passion, are not political. ${ }^{9}$ The confusion arises over the large grey area in between these two extremes. ${ }^{10}$ For example, would targeting government supporters by placing bombs in a crowded market place be a political crime? ${ }^{11}$ What about attempting to kill the wife of a dictator? ${ }^{12}$ Making sense of these borderline cases raises fascinating treaty interpretation issues, and is

\footnotetext{
1 Convention Relating to the Status of Refugees, opened for signature 28 July 1951, 189 UNTS 150 (entered into force 22 April 1954), Article $1 \mathrm{~F}(\mathrm{~b})$.

2 Ibid, Article 1A (2).

3 UNHCR, Guidelines on International Protection No. 5: Application of the Exclusion Clauses: Article 1F of the 1951 Convention relating to the Status of Refugees, HCR/GIP/03/05 (4 September 2003), [2], [8].

4 Michael Kingsley Nyinah, 'Exclusion Under Article 1F: Some Reflections on Context, Principles and Practice' (2000) 12: Supplement 1 International Journal of Refugee Law 295, 302.

5 UNHCR, Background Note on the Application of the Exclusion Clauses: Article 1F of the 1951 Convention relating to the Status of Refugees (4 September 2003), [19]; Minister for Immigration and Multicultural Affairs $v$ Singh (2002) 209 CLR 533, [117] (Kirby J).

6 Igor Ovcharuk $v$ Minister of Immigration \& Multicultural Affairs [1998] 1314 FCA.

7 Zimmerman and Wennholz, 'Article 1F 1951 Convention' in Andreas Zimmerman (ed), The 1951 Convention Relating to the Status of Refugees and its 1967 Protocol: A Commentary (Oxford University Press, 2011) 579, 598; UNHCR, Background Note on the Application of the Exclusion Clauses: Article 1F of the 1951 Convention relating to the Status of Refugees (4 September 2003)[41].

8 Minister for Immigration and Multicultural Affairs v Singh (2002) 209 CLR 533, [103] (Kirby J).

9 Ibid; James Sloan, 'The Application of Article 1F of the 1951 Convention in Canada and the United States' (2000) 12: Supplement 1 International Journal of Refugee Law 222, 242.

10 Minister for Immigration and Multicultural Affairs v Singh (2002) 209 CLR 533, [15] (Gleeson CJ).

11 See Gil v Canada [1995] 1 FC 508.

12 See United Kingdom Immigration Appeals Tribunal case Y (14847) 1997 discussed in Sibylle Kapferer, 'Exclusion Clauses in Europe: A Comparative Overview of State Practice in France, Belgium and the United Kingdom' (2000) 12: Supplement 1 International Journal of Refugee Law 195, 202.
} 
increasingly important in the current climate of heightened fear of terrorism. ${ }^{13}$ Competing theories offer different criteria for distinguishing the political from the non-political. ${ }^{14}$ For example, the predominance test examines the purpose of the crime ${ }^{15}$ and the 'incidence test' focuses on determining whether the crime was part of an uprising. ${ }^{16}$ Alternatively, some jurists, including Justice Callinan, maintain that certain crimes, such as murder, are inherently non-political. ${ }^{17}$

\section{Aim and Approach}

This essay seeks to examine the validity of the predominance test. However, as many of the different perspectives in the literature stem from different theoretical perspectives, it is important to set out this essay's underlying assumptions. This essay approaches the issue from a positivist consent theory perspective. It assumes that international law is based on States' consent to be bound by certain rules, for example by ratifying a treaty. ${ }^{18}$ The aim of treaty interpretation is therefore to determine what the Contracting States agreed to, which can be determined by examining the treaty itself. ${ }^{19}$ So far the jurisprudence and academic discussion on this issue has not conformed to this approach. The meaning of 'non-political' has largely been elaborated from the similar exclusion in the law of extradition. ${ }^{20}$ While the exclusion clauses in refugee law and extradition law are analogous, ${ }^{21}$ over-reliance on extradition jurisprudence is inadvisable for two reasons. Firstly, extradition law and refugee law are quite different. ${ }^{22}$ For example, extradition law is concerned with whether to return a fugitive to a requesting state, whereas refugee law is about granting certain persons special rights. ${ }^{23}$ Secondly, and more importantly, analogising with extradition law can distract jurists from their central task of examining the Refugee Convention itself. The drafters considered, but decided against, including a reference to extradition in the treaty. ${ }^{24}$ This suggests that they

\footnotetext{
13 UNHCR, Background Note on the Application of the Exclusion Clauses: Article 1F of the 1951 Convention relating to the Status of Refugees (4 September 2003) [84].

14 Ibid, [41].

15 Erika Feller et al (eds), Refugee Protection in International Law: UNHCR's Global Consultations on International Protection (Cambridge University Press, 1st ed, 2003), 449.

16 Gil v Canada [1995] 1 FC 508; Sloan, above n 7, 242.

17 Minister for Immigration and Multicultural Affairs $v$ Singh (2002) 209 CLR 533, [161], [167] (Callinan J).

18 Sam Blay, 'The Nature of International Law' in Sam Blay et al. (eds), Public International Law: An Australian Perspective (Oxford University Press, 1997) 1, 14.

19 David Harris, Cases and Materials on International Law (Thomson Reuters, 7th ed, 2010), 674.

20 Walter Kälin and Jörg Künzli, 'Article $1 F(b)$ : Freedom Fighters, Terrorists, and the Notion of Serious NonPolitical Crimes' (2000) 12: Supplement 1 International Journal of Refugee Law 46, 70.

$21 T v$ Secretary of State for the Home Department [1995] 2 All ER 1042.

22 Minister for Immigration and Multicultural Affairs v Singh (2002) 209 CLR 533, [105] (Kirby J).

23 Gil v Canada [1995] 1 FC 508.

24 Conference of Plenipotentiaries on the Status of Refugees and Stateless Persons: Summary Record of the Twenty-Ninth Meeting, Travaux Preparatoires, (28 November 1951).
} 
wanted Article $1 \mathrm{~F}(\mathrm{~b})$ to develop independently of extradition law. Furthermore, as with all treaties, the most important aspect of interpretation is analysing the treaty, rather than external considerations. ${ }^{25}$

This principle is enshrined in Article 31 of the Vienna Convention on the Law of Treaties, which is also customary international law. ${ }^{26}$ It states that a "treaty shall be interpreted in good faith in accordance with the ordinary meaning to be given to the terms of the treaty in their context and in the light of its object and purpose." 27 This essay aims to fill a void in the literature by focussing its analysis on this rule of treaty interpretation.

\section{Argument and Structure}

This essay argues that the predominance test accords with the requirements of Article 31. It will develop this argument by describing the predominance test and then examining whether it is a good faith interpretation of Article $1 \mathrm{~F}(\mathrm{~b})$ and accords with its ordinary meaning, context and object and purpose.

\section{B. The Predominance Test}

The predominance test is the interpretation favoured by United Nations High Commissioner for Refugees (UNHCR) ${ }^{28}$ and certain Contracting States, such as the United Kingdom. ${ }^{29}$ It involves examining whether a political purpose is the predominant characteristic of the crime. ${ }^{30}$ This involves considering whether any political purpose is linked to the crime and, if so, whether the crime is disproportionate to this goal. ${ }^{31}$ Other relevant factors include the target of the crime. ${ }^{32}$ A crime perpetrated against armed agents of the State, such as police or soldiers, is more likely to be political than a crime committed against innocent civilians. ${ }^{33}$

For example, in $T v$ Secretary of State for the Home Department a bomb attack on an airport that killed ten innocent people was not political, even though it was

\footnotetext{
25 Harris, above n 17, 674.

26 Ibid, 677.

27 Vienna Convention on the Law of Treaties, opened for signature 23 May 1969, 1155 UNTS 331 (entered into force 27 January 1980), Article 31.

28 UNHCR, Guidelines on International Protection No. 5: Application of the Exclusion Clauses: Article $1 F$ of the 1951 Convention relating to the Status of Refugees, HCR/GIP/03/05 (4 September 2003), [15].

$29 T v$ Secretary of State for the Home Department [1995] 2 All ER 1042.

30 UNHCR, Background Note on the Application of the Exclusion Clauses: Article $1 F$ of the 1951 Convention relating to the Status of Refugees (4 September 2003), [41].

31 Ibid.

32 Ibid.

33 Minister for Immigration and Multicultural Affairs v Singh (2002) 209 CLR 533, [124] (Kirby J).
} 
motivated by the goal of toppling the government. There was no link between the crime and this political goal because such a bombing would not help bring down the government. Furthermore, such an "atrocious act", ${ }^{34}$ that targeted the public rather than State officials, was disproportionate to this goal. ${ }^{35}$

\section{Good Faith}

The predominance test will be a good faith interpretation of the political crime exception in Article IF (b) if it constitutes a genuine attempt to implement the treaty, rather than a smokescreen for the implementation of decision-makers' own value judgements and political opinions. ${ }^{36}$ The predominance test involves setting out a clear test, with criteria to guide the exercise of the decision-makers' discretion. It is therefore a good faith interpretation.

\section{The Ordinary Meaning}

\section{Introduction}

In order to interpret Article $1 \mathrm{~F}$ (b) it is necessary to examine its ordinary meaning. ${ }^{37}$ Examining the text is crucially important because it expresses the will of the Contracting States and, in particular, how they chose to reconcile the competing objects of the Convention. ${ }^{38}$ However, in this case the text does not contain many clues to its meaning. The Oxford English Dictionary defines political as "[o]f, belonging to, or concerned with the form, organization and administration of a state, and with the regulation of its relations with other states." ${ }^{39}$ This definition does not help distinguish between political and nonpolitical crimes because it fails to specify what aspect of the crime, such as its motive, context or inherent nature, determines its character. The words "nonpolitical crime" are therefore ambiguous and as such consistent with multiple different interpretations.

This section will nonetheless examine some of the key arguments for and against the predominance test being consistent with the ordinary meaning of

\footnotetext{
$34 T v$ Secretary of State for the Home Department [1995] 2 All ER 1042.

35 Ibid.

36 Minister for Immigration and Multicultural Affairs v Singh (2002) 209 CLR 533, [117], [120] (Kirby J).

37 Vienna Convention on the Law of Treaties, opened for signature 23 May 1969, 1155 UNTS 331 (entered into force 27 January 1980), Article 31.

38 A v Minister for Immigration \& Ethnic Affairs (1997) 190 CLR 225 (McHugh J).

39 Political Oxford English Dictionary http://www.oed.com.virtual.anu.edu.au/view/Entry/146887?redire ctedFrom $=$ political\#eid
} 
the text. It argues that the predominance test's consideration of the motive of a crime is consistent with the ordinary meaning of the word crime. However, the proportionality aspect of the predominance test is problematic because it is far more restrictive than the ordinary meaning of political. Criticisms of the predominance test's underlying premise that it is necessary to carefully examine the individual circumstances of a crime in order to determine whether it is political are unconvincing as they rely on a misguided conception of politics that is divorced from the reality that exists in many states of origin.

\section{Motive}

The significance that the predominance test attributes to the motive of a crime is consistent with the ordinary meaning of the word 'crime'. Crimes have both physical and mental elements. The mental element is crucial because without it the action is not a crime. Furthermore, different mental states are associated with different levels of moral culpability and thus change the nature of the offence and the punishment imposed. Given the central significance of a person's mental state in defining a crime, it is logical and consistent with its ordinary meaning to also consider the perpetrator's intentions, when judging whether a crime is political. ${ }^{40}$

\section{Proportionality}

In contrast, the proportionality component of the predominance test does not accord with the ordinary meaning of political. A proportionality analysis involves weighing the means used against the goal they sought to achieve. ${ }^{41}$ This implicitly involves a value judgement about the worthiness of the goal and the 'atrocity' of the means. ${ }^{42}$ However, the word political is neutral. It does not imply that something is 'right' or 'wrong', it merely states that it is associated with the governance of a country. ${ }^{43}$ The proportionality part of the predominance test therefore interprets the word 'political' in Article 1F (b) in a manner that is more restrictive than its ordinary meaning. ${ }^{44}$

\footnotetext{
$40 \quad R v$ Governor of Pentonville Prison; Ex parte Cheng [1973] AC 931 (Lord Diplock); Minister for Immigration and Multicultural Affairs $v$ Singh (2002) 209 CLR 533, 122 (Kirby J).

41 UNHCR, Handbook on Procedures and Criteria for Determining Refguee Status under the 1951 Convention and the 1967 Protocol Relating to the Status of Refugees, HCR/IP/4/Rev.1, (1979, reedited January 1992), [152]. 42 Quinnv Robinson discussed in Gilv Canada [1995] 1 FC 508 and Minister for Immigration and Multicultural Affairs v Singh (2002) 209 CLR 533, [113] (Kirby J).

43 Political Oxford English Dictionary http://www.oed.com.virtual.anu.edu.au/view/Entry/146887?redire ctedFrom $=$ political\#eid

44 Quinn v Robinson discussed in Gilv Canada [1995] 1 FC 508 and Minister for Immigration and Multicultural Affairs v Singh (2002) 209 CLR 533, [113] (Kirby J).
} 
Terrorism provides the perfect example. According to the predominance test terrorist acts will almost never be political because they are a disproportionate response to their supposed political goal. ${ }^{45}$ However, while there is no universally accepted definition of terrorism, a common element that consistently recurs when describing it is that it consists of "criminal acts intended or calculated to provoke a state of terror in the general public, a group of persons or particular persons for political purposes" (emphasis added). ${ }^{46}$ As terrorism is a tactic used to achieve political goals, and as such is widely perceived as political, it is artificial and counter-intuitive to state, as the predominance test does, that it can almost never be political.

Proponents of the predominance test propose various arguments why the proportionality aspect of the test is consistent with the ordinary meaning of political. One such argument is that using disproportionately violent means to achieve a political goal suggests that the crime was not really motivated by the political goal at all. It must have been motivated by something else. ${ }^{47}$ This is unconvincing because the history of human conflict demonstrates that political goals are exactly the kind of motivation that causes people to lose all inhibitions and commit horrendous acts. ${ }^{48}$ Another argument in defence of excluding atrocious crimes against civilians, such as terrorism, from the category of political crimes maintains that political crimes are directed against the government of a country. By contrast, indiscriminate acts of terrorism are directed against society and the people and are therefore not political. ${ }^{49}$ However this creates an artificial distinction. Politics and society are inherently interconnected. It is therefore perfectly possible that groups would use attacks against innocent people to achieve a political goal..$^{50}$

\section{Inherent Meaning}

While the proportionality component of the predominance test does not accord with the text of Article $1 \mathrm{~F}(\mathrm{~b})$, one interesting theoretical argument goes further and maintains that the entire predominance test is contrary to the ordinary meaning of political. Justice Callinan in Minister for Immigration and Multicultural Affairs $v$ Singh (Singh) argued that violence is, by its very nature, non-political. In his view, politics is concerned with the rational and civilised governance of societies. ${ }^{51}$ Violence undermines this peaceful rationality and

\footnotetext{
45 UNHCR, Guidelines on International Protection No. 5: Application of the Exclusion Clauses: Article $1 F$ of the 1951 Convention relating to the Status of Refugees, HCR/GIP/03/05 (4 September 2003), [25].

46 GA Resolution 53/108 on Measures to Eliminate International Terrorism quoted in Feller, above n $13,442$.

47 Minister for Immigration and Multicultural Affairs v Singh (2002) 209 CLR 533, [46] (Gaudron J).

48 Minister for Immigration and Multicultural Affairs $v$ Singh (2002) 209 CLR 533, [107], [127] (Kirby J).

49 Eain $v$ Wilkes extracted in Gil $v$ Canada [1995] 1 FC 508.

50 GA Resolution 53/108 on Measures to Eliminate International Terrorism quoted in Feller, above n $13,442$.

51 Minister for Immigration and Multicultural Affairs v Singh (2002) 209 CLR 533, [161] (Callinan J).
} 
therefore it can only ever be an unacceptable and abhorrent intrusion into the realm of politics. Violence destroys politics and therefore cannot itself be political. ${ }^{52}$ Therefore crimes, such as murder and terrorism, will always be nonpolitical and the predominance test's examination of motivation, proportionality and other factors is redundant. ${ }^{53}$

While the crystal clear simplicity and purity of this conception of politics is alluring, Justice Kirby in that case raised convincing arguments about why it does not reflect the ordinary, and much more complicated, meaning of 'political'. He pointed out that, while it is true that in stable liberal democracies like Australia violence is not part of our political processes, this is not a universal truth. In other countries violence is an endemic part of the political system, and may be the only way to achieve liberation from an oppressive government. ${ }^{54}$ In fact, one reason refugees flee to countries like Australia is because they are drawn by our radically different and peaceful political culture. Article $1 F(b)$ is intended to be applied to people escaping countries where they have been persecuted, and which are therefore more likely to have a dysfunctional and violent political system. ${ }^{55}$ It would undermine this purpose to base our understanding of the ordinary meaning of 'political' on the conditions existing in the states of refuge, rather than the states of origin, where the crimes most likely occurred. ${ }^{56}$

Therefore, while the predominance test is generally consistent with the ordinary meaning of 'non-political crime', its proportionality component is not.

\section{E. The Context}

\section{Introduction}

It is also necessary to consider the context of the political crime exception, which includes Article IF (b)'s reference to serious crimes and Articles 1F (a) and (c). ${ }^{57}$ This section argues that, while these provisions appear to raise further arguments against the proportionality component of the predominance test, the proportionality test is in fact consistent with them.

\footnotetext{
52 Ibid.

53 Ibid, [167] (Callinan J).

54 Ibid, [107], [127] (Kirby J)

55 Convention Relating to the Status of Refugees, opened for signature 28 July 1951, 189 UNTS 150 (entered into force 22 April 1954), Article 1A(2).

56 Minister for Immigration and Multicultural Affairs v Singh (2002) 209 CLR 533, [106] (Kirby J).

57 Vienna Convention on the Law of Treaties, opened for signature 23 May 1969, 1155 UNTS 331 (entered into force 27 January 1980), Article 31.
} 


\section{Serious Crime}

As stated above, Article 1F (b) excludes persons who there are serious reasons for considering have committed "a serious non-political crime" (emphasis added). Therefore, if a crime is not serious the issue of whether it is political does not arise, because it will not constitute grounds for exclusion under Article 1F (b). However the proportionality test's examination of the consequences and means of perpetrating a crime, as well as its targets, would appear to come close to classifying crimes as non-political, merely because they are serious. This would be inappropriate because it was clearly the Contracting States' intention that a person should not be denied refugee status because they committed a political crime, even if it was serious. ${ }^{58}$

However, in practice this problem does not arise because the threshold for 'seriousness' is much lower than the threshold for 'disproportionality'. For example, any murder or robbery will be serious, ${ }^{59}$ but it will only be disproportionate if it was carried out in a way that could not be justified by the political motive ${ }^{60}$ For instance, while attempted murder is a serious crime it would be proportionate if it were perpetrated via a targeted attack on the wife of a dictator because such an action is very likely to achieve the desired political aim of harming the dictator and it would be very unlikely to result in the deaths of innocent bystanders. ${ }^{61}$ A terrorist bombing of an airport, on the other hand would be serious and disproportionate because it unlikely to achieve actual political change and involves killing civilians. ${ }^{62}$

\section{Articles $1 F(a)$ and $(c)$}

These provisions exclude from refugee status anyone who "has committed a crime against peace, a war crime, or a crime against humanity"63 or "has been guilty of acts contrary to the purposes and principles of the United Nations." ${ }^{64}$ Both of these exclusions could cover horrendous acts, such as terrorism. ${ }^{65}$ As explained above, the proportionality part of the predominance test is inconsistent with the ordinary meaning of political. This would suggest that this proportionality analysis should be abandoned because such acts would nevertheless be excluded by Articles IF (a) and (c). However, while terrorism

\footnotetext{
58 Minister for Immigration and Multicultural Affairs v Singh (2002) 209 CLR 533, [120] (Kirby J).

59 Sloan, above $\mathrm{n} 7,241$.

$60 \quad T v$ Secretary of State for the Home Department [1995] 2 All ER 1042.

61 United Kingdom Immigration Appeals Tribunal case Y (14847) 1997 discussed in Kapferer, above n 10, 202.

$62 T v$ Secretary of State for the Home Department [1995] 2 All ER 1042.

63 Convention Relating to the Status of Refugees, opened for signature 28 July 1951, 189 UNTS 150 (entered into force 22 April 1954), Article $1 \mathrm{~F}(\mathrm{a})$.

64 Ibid, Article $1 \mathrm{~F}(\mathrm{c})$.

65 UNHCR, Background Note on the Application of the Exclusion Clauses: Article IF of the 1951 Convention relating to the Status of Refugees (4 September 2003), [83].
} 
can constitute a crime against humanity and therefore be excluded under Article $1 \mathrm{~F}(\mathrm{a})$, this involves the terrorism being part of coordinated attack on the civilian population. ${ }^{66}$ This is an additional requirement that is not present when deciding whether to exclude a terrorist act under Article 1F (b). Furthermore, a terrorist attack would only breach Article $1 F(c)$ if it had a major impact upon international relations. ${ }^{67}$ This would clearly not cover all terrorist attacks. Therefore, while Articles 1F (a), (b) and (c) are all capable of excluding terrorists, they apply in different situations.$^{68}$ Article $1 \mathrm{~F}(\mathrm{~b})$ is most relevant for the vast majority of terrorist attacks and as such the applicability of Articles $1 F(a)$ and (c) to terrorism is not an argument in favour of abandoning the predominance test's proportionality requirement. ${ }^{69}$

Thus the predominance test is consistent with the context of the political crime exception.

\section{F. The Object and Purpose}

\section{Introduction}

The object and purpose of the provision is another vital consideration in determining whether the predominance test is a valid interpretation of the phrase 'non-political crime'.$^{70}$ However, because this phrase is an exception to an exclusion clause, it exists within a complicated web of interrelated purposes that need to be untangled before it is possible to analyse whether the predominance test furthers them or undermines them. This section therefore begins by describing these objects. It argues that the Refugee Convention has a humanitarian object and purpose, whereas Article $1 \mathrm{~F}(\mathrm{~b})$ is aimed at protecting the status of refugees and the security and sovereignty of receiving states, as well as encouraging ratification of the Refugee Convention. The political crime exception is designed to protect those who commit political crimes merely by exercising their human rights, prevent people being returned to states of origin to face unfair trials and extend protection to freedom fighters. This section argues that the predominance test, and particularly the proportionality component, furthers all these objects.

66 UNHCR, Guidelines on International Protection No. 5: Application of the Exclusion Clauses: Article $1 F$ of the 1951 Convention relating to the Status of Refugees, HCR/GIP/03/05 (4 September 2003), [13].

67 Ibid, [17].

68 UNHCR, Background Note on the Application of the Exclusion Clauses: Article 1F of the 1951 Convention relating to the Status of Refugees (4 September 2003), [80], [83].

69 Ibid, [81], [83].

70 Vienna Convention on the Law of Treaties, opened for signature 23 May 1969, 1155 UNTS 331 (entered into force 27 January 1980), Article 31. 


\section{Article $1 \mathrm{~F}(\mathrm{~b})$}

The Refugee Convention itself has the humanitarian purpose of protecting refugees. ${ }^{71}$ This is balanced by the purposes of Article 1F (b). An examination of the travaux preparatoires reveals that this Article has three purposes. Firstly, the Contracting States did not want to diminish the unique international standing of refugees by bestowing this status on people who were unworthy of it. ${ }^{72}$ Secondly, this exclusion was a concession to the sovereign right of States to control who enters their territory and in particular their right and moral duty to exclude those who may pose a threat to their communities. ${ }^{73}$ Finally, the drafters of the Convention hoped that protecting States' vital interests in this way would make them more willing to ratify the Refugee Convention and thus commit themselves to protecting refugees. ${ }^{74}$ The drafters were pragmatic and recognised that it would be counter-productive to extend refugee rights to criminals if this discouraged States from ratifying the Refugee Convention and thus denied all refugees these rights. ${ }^{75}$

\section{The Political Crimes Exception}

The object and purpose of the political crimes exception to Article $1 \mathrm{~F}(\mathrm{~b})$ is more difficult to discern. It is not clear from the text of the Refugee Convention itself and it is not discussed in the travaux preparatoires. It is therefore necessary to turn to the discussion of this exception by the UNHCR and in the case law.

The UNHCR states in its document Interpreting Article 1 of the 1951 Convention Relating to the Status of Refugees that the purpose of the political crime exception is to protect those who breach the repressive laws of their state of origin merely by exercising their human rights, for example by openly expressing a political opinion. ${ }^{76}$ While this would undoubtedly serve the purpose of the Refugee Convention it seems too restrictive to be the only purpose, as most states of refuge would not consider such a crime to be 'serious'. ${ }^{77}$

\footnotetext{
71 UNHCR, Background Note on the Application of the Exclusion Clauses: Article 1F of the 1951 Convention relating to the Status of Refugees (4 September 2003), [3].

72 Conference of Plenipotentiaries on the Status of Refugees and Stateless Persons: Summary Record of the Twenty-Ninth Meeting, Travaux Preparatoires, (28 November 1951); UNHCR, Guidelines on International Protection No. 5: Application of the Exclusion Clauses: Article $1 F$ of the 1951 Convention relating to the Status of Refugees, HCR/GIP/03/05 (4 September 2003), [2].

73 Ibid; UNHCR, Handbook on Procedures and Criteria for Determining Refguee Status under the 1951 Convention and the 1967 Protocol Relating to the Status of Refugees, HCR/IP/4/Rev.1, (1979, reedited January 1992), [151].

74 Conference of Plenipotentiaries on the Status of Refugees and Stateless Persons: Summary Record of the Twenty-Ninth Meeting, Travaux Preparatoires, (28 November 1951).

75 Ibid.

76 UNHCR, Interpreting Article 1 of the 1951 Convention Relating to the Status of Refugees (April 2001), [46].

77 Igor Ovcharuk $v$ Minister of Immigration \& Multicultural Affairs [1998] 1314 FCA (Branson J).
} 
In $R v$ Governor of Pentonville Prison; Ex parte Cheng (Cheng), Lord Diplock suggested two purposes for the "offence of a political character" exception in the United Kingdom's Extradition Act 1870. The first was avoiding entangling the United Kingdom in other nations' domestic dissension. ${ }^{78}$ This is not relevant to the political crime exception in Article $1 F$ (b) because making refugee determinations inherently involves making judgements about the domestic situation of other nations. In order to determine whether someone faces persecution in their state of origin it is necessary make an assessment of the circumstances existing in that country, ${ }^{79}$ which may have diplomatic consequences.

The second reason was preventing a fugitive being returned to a country where his or her trial would be unfair because of political bias. ${ }^{80}$ This purpose is far more pertinent because it upholds the Convention's purpose of protecting the vulnerable from persecution. If a trial would be so tainted by political considerations that it would amount to political persecution then it accords with the humanitarian goals of the Convention to extend refugee status to that person, even if they have committed a serious crime. ${ }^{81}$

Justice Kirby suggested another purpose of the political crime exception in Singh which, unlike Cheng, was a case dealing with the Refugee Convention. He argued that this exception was intended to protect people who commit serious crimes "for objectives that they viewed as justified and even noble", ${ }^{82}$ such as the Indians who struggled for independence from the British. ${ }^{83}$ The political crime exception was therefore designed to prevent those who broke the law in the pursuit of self-determination being denied the benefits of refugee status. ${ }^{84} \mathrm{At}$ first it seems unlikely that the colonial European states that made up the majority of original parties to the Refugee Convention would have wanted to protect those who sought to throw off the colonial yoke. However, self-determination is one of the fundamental principles of the United Nations, ${ }^{85}$ to which they belong and under whose auspices the Refugee Convention was drafted. ${ }^{86}$ Furthermore, there are hints in European extradition cases, such as Cheng, that the political

$78 R v$ Governor of Pentonville Prison; Ex parte Cheng [1973] AC 931 (Lord Diplomatic).

79 UNHCR, Handbook on Procedures and Criteria for Determining Refguee Status under the 1951 Convention and the 1967 Protocol Relating to the Status of Refugees, HCR/IP/4/Rev.1, (1979, reedited January 1992).

$80 R v$ Governor of Pentonville Prison; Ex parte Cheng [1973] AC 931 (Lord Diplomatic).

81 Zimmerman and Wennholz, above n 5, 598.

82 Minister for Immigration and Multicultural Affairs $v$ Singh (2002) 209 CLR 533, [97] (Kirby J).

83 Ibid.

84 Ibid.

85 Charter of the United Nations, Article 1(2).

86 Convention Relating to the Status of Refugees, opened for signature 28 July 1951, 189 UNTS 150 (entered into force 22 April 1954), Preamble. 
crime exception in extradition law may also have been motivated by a concern to protect 'freedom-fighters', such as Garibaldi. ${ }^{87}$ Therefore this probably is a purpose of the exception.

\section{Consistency With These Objects}

The predominance test serves the purpose of ensuring that only the 'worthy' are granted refugee status. As explained above one of the purposes of Article $1 \mathrm{~F}(\mathrm{~b})$ is to protect the status of refugees by excluding unworthy applicants. Some of the purposes of the political crime exception are very similar. Presumably the reason why the drafters sought to protect freedom fighters and those who merely exercised their human rights, even if they were criminals, was because they were nonetheless viewed as being worthy of refugee status. ${ }^{88}$ 'Worthiness' is a value-laden concept that inherently imports considerations of moral culpability. The predominance test is flexible enough to allow decision-makers to consider the circumstances that would affect whether any particular applicant deserved refugee status, such as the motive of the crime, its proportionality and its target. ${ }^{89}$

The predominance test also furthers Article 1F(b)'s purpose of allowing States to protect their communities from dangerous criminals. As discussed above, the ordinary meaning of political is completely neutral. If the ordinary meaning were followed in the interpretation of the political crime exception a terrorist who killed innocent people would be just as entitled to protection as a refugee as a peaceful activist who angered an oppressive government by distributing pamphlets. ${ }^{90}$ This would completely undermine the purpose of protecting the communities of receiving states. The predominance test is flexible enough to address this problem by allowing decision-makers to exclude dangerous criminals who have committed disproportionately violent crimes against the innocent. ${ }^{91}$

Furthermore, by upholding the objects of excluding unworthy and dangerous criminals, the predominance test also implements the related object of maintaining political goodwill for the refugee system. If unworthy applicants, such as terrorists and other dangerous criminals, are granted refugee status it may cause the people of the states of refuge to perceive refugees as threats who

$87 R v$ Governor of Pentonville Prison; Ex parte Cheng [1973] AC 931; T $v$ Secretary of State for the Home Department [1995] 2 All ER 1042.

88 Minister for Immigration and Multicultural Affairs $v$ Singh (2002) 209 CLR 533, [97] (Kirby J); UNHCR, Interpreting Article 1 of the 1951 Convention Relating to the Status of Refugees (April 2001), [46].

89 UNHCR, Handbook on Procedures and Criteria for Determining Refugee Status under the 1951 Convention and the 1967 Protocol Relating to the Status of Refugees, HCR/IP/4/Rev.1, (1979, reedited January 1992), [152].

90 Quinn v Robinson extracted in Gil v Canada [1995] 1 FC 508.

$91 T v$ Secretary of State for the Home Department [1995] 2 All ER 1042. 
are undeserving of protection. ${ }^{92}$ This may cause them to question the entire refugee system. Democratic governments would be aware of this prevailing attitude and respond accordingly by restricting refugee rights. Hostility to refugees is already high, making it difficult for many vulnerable people to access the protection they need..$^{93}$ Allowing the refugee system to turn receiving states into a safe haven for terrorists and those who have committed other 'atrocious' crimes would only aggravate the situation.

Finally, the predominance test is also consistent with the political crime exception's object of not returning someone to face a trial that is tainted by political considerations. If a decision-maker decides that there are serious reasons for considering that a person committed a crime that was so violent and abhorrent that it was disproportionate to its motive and therefore not political, it is likely that the political aspect of any trial would be completely overshadowed by its criminal aspect. ${ }^{94}$ For example, in a trial of a terrorist attack that killed many civilians the political motive would be almost irrelevant. Even if the authorities conducting the trial looked unfavourably on the suspect because of his or her political motivation, they would be far more concerned with the deaths of innocent people. In contrast, distributing political pamphlets would not be disproportionate. A person who committed this crime would therefore pass the predominance test. This means they would not be put at risk of being returned to their state of origin where any trial they would face would be dominated by political bias because their political motivation for distributing the pamphlets would be the central aspect of the crime..$^{95}$ Therefore, the proportionality aspect of the predominance test allows decision-makers to protect those applicants who are risk of facing an unfair trial, but exclude those whose trial would mainly be concerned with criminal, rather than political, matters.

\section{Conclusion}

Therefore the predominance test, and particularly its proportionality component, accords with the objects of the provision.

92 UNHCR, Background Note on the Application of the Exclusion Clauses: Article IF of the 1951 Convention relating to the Status of Refugees (4 September 2003), [84]; Nyinah, above n 3, 310.

93 Geoff Gilbert, 'Running Scared Since 9/11: Refugees, UNHCR and the Purposive Approach to Treaty Interpretation' in James C Simeon (ed), Critical Issues in International Refugee Law: Strategies Toward Interpretative Harmony (Cambridge University Press, 2010), 85-86.

94 Immigration and Naturalization Service v Aguirre-Aguirre 526 US 415 (1998), 429-431.

95 Kälin, above n 18, 64. 


\section{G. Concluding remarks}

The predominance test is an excellent interpretation of the political crime exception. It is a good faith interpretation that generally accords with the ordinary meaning, context and purpose of the provision. While the proportionality component of the test is contrary to the ordinary meaning of the words used, this is acceptable because it is crucial to give effect to the provision's objects and purposes. This test should therefore be applied by all Contracting States, as well as the UNHCR, in the interests of consistency, predictability and fairness.

\section{Bibliography}

\section{Articles/Books/Reports}

Blay, Sam, 'The Nature of International Law' in Sam Blay et al. (eds), Public International Law: An Australian Perspective (Oxford University Press, 1997) 1

Feller, Erika et al (eds), Refugee Protection in International Law: UNHCR's Global Consultations on International Protection (Cambridge University Press, 1st ed, 2003)

Gilbert, Geoff, 'Running Scared Since 9/11: Refugees, UNHCR and the Purposive Approach to Treaty Interpretation' in James C Simeon (ed), Critical Issues in International Refugee Law: Strategies Toward Interpretative Harmony (Cambridge University Press, 2010)

Goodwin-Gill, Guy and McAdam, Jane, The Refugee in International Law (Oxford University Press, 3rd ed, 2007)

Grahl-Madsen, Atle, The Status of Refugees in International Law (Leyden, A. W. Sijthoff, 1st ed, 1966)

Harris, David, Cases and Materials on International Law (Thomson Reuters, 7th ed, 2010)

Hathaway, James, The Rights of Refugees Under International Law (Cambridge University Press, 1st ed, 2005)

Kälin, Walter and Künzli, Jörg, 'Article $1 F(b)$ : Freedom Fighters, Terrorists, and the Notion of Serious Non-Political Crimes' (2000) 12: Supplement 1 International Journal of Refugee Law 46 
The ANU Undergraduate Research Journal

Kapferer, Sibylle, 'Exclusion Clauses in Europe: A Comparative Overview of State Practice in France, Belgium and the United Kingdom' (2000) 12: Supplement 1 International Journal of Refugee Law 195

Nyinah, Michael Kingsley, 'Exclusion Under Article 1F: Some Reflections on Context, Principles and Practice' (2000) 12: Supplement 1 International Journal of Refugee Law 295

'Safeguarding the Rights of Refugees Under the Exclusion Clause: Summary Findigns of the Project and a Lawyers Committee for Human Rights Perspective' (2000) 12: Supplement 1 International Journal of Refugee Law 317

Sloan, James, 'The Application of Article 1F of the 1951 Convention in Canada and the United States' (2000) 12: Supplement 1 International Journal of Refugee Law 222

Zimmerman and Wennholz, 'Article 1F 1951 Convention' in Andreas Zimmerman (ed), The 1951 Convention Relating to the Status of Refugees and its 1967 Protocol: A Commentary (Oxford University Press, 2011) 579.

\section{Cases}

A v Minister for Immigration \& Ethnic Affairs (1997) 190 CLR 225.

Gil v Canada [1995] 1 FC 508

Igor Ovcharuk $v$ Minister of Immigration \& Multicultural Affairs [1998] 1314 FCA

$R v$ Governor of Pentonville Prison; Ex parte Cheng [1973] AC 931

Immigration and Naturalization Service v Aguirre-Aguirre 526 US 415 (1998)

Minister for Immigration and Multicultural Affairs v Singh (2002) 209 CLR 533

T v Secretary of State for the Home Department [1995] 2 All ER 1042

\section{Treaties}

Charter of the United Nations

Convention Relating to the Status of Refugees, opened for signature 28 July 1951, 189 UNTS 150 (entered into force 22 April 1954)

Vienna Convention on the Law of Treaties, opened for signature 23 May 1969, 1155 UNTS 331 (entered into force 27 January 1980). 


\section{Other}

A Thematic Compilation of Executive Committee Conclusions, Office of the United Nations High Commissioner for Refugees, Division of International Protection Services, 4th ed, August 2009

Conference of Plenipotentiaries on the Status of Refugees and Stateless Persons: Summary Record of the Twenty-Ninth Meeting, Travaux Preparatoires, (28 November 1951)

Political Oxford English Dictionary http://www.oed.com.virtual.anu.edu.au/ view/Entry/146887?redirectedFrom=political\#eid

UNHCR, Background Note on the Application of the Exclusion Clauses: Article $1 F$ of the 1951 Convention relating to the Status of Refugees (4 September 2003)

UNHCR, Guidelines on International Protection No. 5: Application of the Exclusion Clauses: Article $1 F$ of the 1951 Convention relating to the Status of Refugees, HCR/GIP/03/05 (4 September 2003)

UNHCR, Handbook on Procedures and Criteria for Determining Refguee Status under the 1951 Convention and the 1967 Protocol Relating to the Status of Refugees, HCR/IP/4/Rev.1, (1979, reedited January 1992)

UNHCR, Interpreting Article 1 of the 1951 Convention Relating to the Status of Refugees (April 2001) 